\title{
Efficiency of fluid organomineral fertilizer with pig slurry in nitrogen and phosphorus availability
}

\author{
Eficiência de fertilizante fluido organomineral com dejeto suíno na disponibilidade de nitrogênio e \\ fósforo
}

\author{
Marco André Grohskopf ${ }^{1 \star}$, Caio Vilela Cruz ${ }^{1}$, Natália Rodrigues Ferreira Eloy ${ }^{1}$, Dirceu Maximino \\ Fernandes ${ }^{1}$, Leonardo Theodoro Büll ${ }^{1}$, Juliano Corulli Corrêa ${ }^{2}$
}

${ }^{1}$ Universidade Estadual Paulista, Botucatu, SP, Brasil. *Autor para correspondência: marcogrohskopf@gmail.com.

${ }^{2}$ Embrapa Suínos e Aves, Concórdia, SC, Brasil.

Submission: 25/09/2017 | Acceptance: 10/12/2019

\begin{abstract}
The use of pig slurry (PS) in fluid fertilizer formulation, for nitrogen $(\mathrm{N})$ and phosphorus $(\mathrm{P})$ supply, consists of an innovative technology due to this waste reuse in the environment. The objective of this study was to assess the agronomic efficiency of fluid organomineral fertilizers with PS concerning solid and fluid forms of soluble minerals as a source of $\mathrm{N}$ and $\mathrm{P}$ in a Typic Quartzipsamment (Entisol) and Typic Hapludox (Oxisol). Two experiments were carried out in a greenhouse, with three sequential cultivations in a completely randomized design. Experiment 1: was composed of $\mathrm{N}$ and presented the treatments WithoutNitrogen (N-W), solid mineral (N-SM), fluid mineral (N-FM), and fluid with PS (N-FO). Experiment 2: was composed of $P$ and presented the treatments Without-Phosphorus (P-W), solid mineral (P-SM), fluid mineral (P-FM), and fluid with PS (P-FO). The fertilizer N-FO presented a lower $\mathrm{N}$ use efficiency by crops in Entisol when compared to the granular fertilizer $\mathrm{N}-\mathrm{SM}$, but a higher efficiency in Oxisol. For phosphorus, the fertilizer P-FO was more efficient concerning the solid mineral source P-SM in both Oxisol and Entisol soils. Fluid organomineral fertilizer with PS demonstrated to be a promising source of $\mathrm{N}$ and $\mathrm{P}$ for crop fertilization, especially in sandy soils, however, more studies are needed with this fertilizer type and its effect on plants and into acid soils of variable charges.
\end{abstract}

KEYWORDS: liquid manure, liquid and solid fertilizer, plant nutrition.

\section{RESUMO}

O uso dejeto líquido de suíno (DLS) na formulação de fertilizantes fluidos, para o fornecimento de nitrogênio $(\mathrm{N})$ e fósforo $(\mathrm{P})$, é uma tecnologia inovadora devido ao reaproveitamento deste resíduo no meio ambiente. $\mathrm{O}$ objetivo do trabalho foi avaliar a eficiência agronômica de fertilizantes organominerais fluidos com DLS em relação às formas sólidas e fluidas de minerais solúveis como fonte de $\mathrm{N}$ e $\mathrm{P}$ em Neossolo Quartzarênico (RQo) e Latossolo Vermelho (LVdf). Dois experimentos foram conduzidos simultaneamente em casa de vegetação, com três cultivos sequenciais no delineamento inteiramente casualizado. $\mathrm{O}$ experimento $1 \mathrm{com} \mathrm{N}$ compreendeu os tratamentos: sem nitrogênio (Sem- $\mathrm{N}$ ), mineral sólido (MS-N), mineral fluido (MF-N) e fluido com DLS (OF-N); já o experimento $2 \mathrm{com} P$ traz os tratamentos: sem fósforo (Sem-P), mineral sólido (MS-P), mineral fluido (MF-P) e fluido com DLS (OF-P). Os fertilizante OF-N foi menos eficiente no aproveitamento de $\mathrm{N}$ pelas culturas em relação ao fertilizante MS-N em grânulo na condição de LVdf, e superior ao mesmo em RQo. Para o fósforo o fertilizante OF-P foi mais eficiente em relação a fonte sólida mineral MS-P na condição de RQo e apresentou a mesma eficiência em LVdf. O fertilizante organomineral fluido elaborado com DLS demonstrou ser uma fonte promissora na adubação de culturas como fonte de $\mathrm{N}$ e $\mathrm{P}$, principalmente, em solo de textura arenosa, entretanto, mais estudos são necessários com este tipo de fertilizante e seus efeitos sobre as plantas e em solos ácidos de cargas variáveis.

PALAVRAS-CHAVE: dejeto líquido, fertilizante sólido e líquido, nutrição de plantas.

\section{INTRODUCTION}

Developing and producing new fertilizers are strategic for agribusiness due to high demand and dependence in agriculture. Frequent and high-dose applications of phosphate and nitrogen fertilizers to 
maintain or increase crop yield are related to nitrogen $(\mathrm{N})$ and phosphorus $(\mathrm{P})$ deficiency within the soil-plant system in weathered soils (CAMARGO et al. 2014, DORNELES et al. 2015).

New technologies of phosphate fertilizers are essential due to adsorption and precipitation reactions which control $P$ destination from fertilizers (MONTALVO et al. 2015), mainly the adsorption in soils with crystalline forms of oxides, hydroxides or oxyhydroxides of iron and aluminum due to the high binding energy between phosphate anions and mineral surface functional groups (BOLAN et al. 2013, FINK et al. 2016). For weathered soils of acid characteristics, it depends on the degree to which the phosphate ions form soluble complexes (SHUAI \& ZINATI 2009, SHEN et al. 2011).

Conversely, nitrogen efficiency of $\mathrm{N}$ fertilizers is related to processes such as desorption, adsorption, leaching, volatilization, nitrification, denitrification, immobilization, and mineralization, which are usually mediated by microorganisms and affected by climatic factors (ZHANG et al. 2011, MÜLLER et al. 2011). As a result, a frequent and often high-dose application of $\mathrm{N}$ fertilizers is needed whether or not the content of soil organic matter (SOM) is sufficient for $\mathrm{N}$ supply since there is no synchronism between its release and crop demand (MALTAS et al. 2013, GROHSKOPF et al. 2015).

Fluid fertilizers have an agronomic efficiency equal to or greater than the traditional solid one (BERTRAND et al. 2006), but they are still little used as N and P sources. The prospects of use, however, are promising due to some advantages over solid fertilizers, for instance, production cost, ease of handling, uniformity of application, lower losses, formulation versatility, ease of calibration, less manpower use, reduced fertilization cost, and operating yield (REHM \& LAMB 2010).

Pig farming has been growing and thereby increasing the generated amount of waste. This fact raises concerns about the proper disposal of this residue, which is usually applied as fertilizer on farmlands (VEIGA et al. 2012, MAFRA et al. 2014). The use of pig slurry (PS) as fertilizer demands the development of technologies for application, that would enable taking advantage of its favorable effects on soil attributes and agricultural production. However, it should be considered that this residue has a quite variable elemental composition, mainly regarding the type of pig rearing management (VEIGA et al. 2012).

Fluid fertilizers can be used in organomineral form, through reusing liquid organic residues such as pig slurry and also combined with balancing mineral sources. This form leads to changes in the efficiency of $\mathrm{N}$ and $\mathrm{P}$ available in the soil-plant system concerning mineral fertilizers in fluid or solid forms used alone. This hypothesis is intended to be demonstrated in this paper. Considering that studies on the use of fluid fertilizers with pig slurry are still scarce, their assessment will allow knowing their efficiency, in addition to contributing to good practices of fertilizer recommendation.

Thus, this study aimed to assess the agronomic efficiency of fluid fertilizers with pig slurry concerning fluid or solid forms with soluble minerals as a source of nitrogen and phosphorus to plants in a Typic Quartzipsamment and Typic Hapludox.

\section{MATERIAL AND METHODS}

Two experiments were carried out in this study, both conducted simultaneously under greenhouse conditions with the controlled environment at the São Paulo State University, Botucatu, São Paulo, Brazil. The first experiment assessed fluid fertilizers with pig slurry regarding nitrogen supply, whereas the second experiment assessed phosphorus supply. Two soil classes were used: a clayey Typic Hapludox (Oxisol) and a sandy Typic Quartzipsamment (Entisol).

Soil samples were collected in Botucatu, SP from natural areas with herbaceous vegetation, without agricultural use, and without fertilizer and corrective application. Samples were taken at a depth of 0.0 to $0.2 \mathrm{~m}$ and soil chemical and physical attributes (Table 1) were determined according to the method described by VAN RAIJ et al. (2001). Subsequently, soil samples were sieved through a $4 \mathrm{~mm}$ mesh, removing roots, straws, and clods. Soil acidity was corrected by using dolomitic limestone $(100 \%$ total relative neutralizing power), aiming to raise the base saturation to $70 \%$. These samples were incubated for 30 days under plastic canvas and with moisture around $80 \%$ of the field capacity of each soil type.

Typic Hapludox is characterized as oxidic soils (Oxisols) with a predominance of crystalline forms of iron oxides (goethite and hematite); in the clay fraction, kaolinite predominates, followed by 2:1 clay minerals with hydroxy-Al polymers between layers and, at smaller proportions, gibbsite and quartz occur (CARVALHO et al. 1983). On the other hand, a Typic Quartzipsamment (Entisol) presents the predominance of quartz, but in the clay fraction, kaolinite predominates and alterable primary minerals are absent (CARVALHO et al. 1983).

Both experiments were conducted in a completely randomized design in a $2 \times 4$ factorial scheme with four replications. Treatments were composed of three types of fertilizers (solid mineral, fluid mineral and fluid 
organomineral) and a control (non-fertilization with the element under study) in interaction with Oxisol and Entisol soils. Experimental units were composed of pots containing $10.0 \mathrm{~kg}$ dry soil (Table 1).

Table 1. Initial attributes of the 0.0 to $0.2 \mathrm{~m}$ layer of Typic Hapludox (Oxisol) and Typic Quartzipsamment (Entisol) used in the experiment. Botucatu, SP, Brazil.

\begin{tabular}{|c|c|c|c|c|c|c|c|c|c|c|c|c|c|}
\hline Soil & $\begin{array}{c}\mathrm{pH} \\
\mathrm{CaCl}_{2}\end{array}$ & $\begin{array}{l}\text { BS } \\
\%\end{array}$ & $\mathrm{Al}^{+3}$ & $\begin{array}{l}\mathrm{H}+\mathrm{Al} \\
---\mathrm{m}\end{array}$ & $\begin{array}{l}\mathrm{Ca}^{+2} \\
\mathrm{nol}_{\mathrm{c}} \mathrm{dm}\end{array}$ & $\mathrm{Mg}^{+2}$ & $\mathrm{~K}^{+}$ & $\begin{array}{c}\mathrm{P}_{\text {resin }} \\
\mathrm{mg} \mathrm{dm}^{-3}\end{array}$ & Clay & $\begin{array}{l}\text { Sand } \\
\mathrm{g} \mathrm{kg}^{-1}\end{array}$ & Silt & $\begin{array}{c}\mathrm{SOM} \\
\mathrm{g} \mathrm{dm}^{-3}\end{array}$ & $\begin{array}{c}\mathrm{SD} \\
\mathrm{g} \mathrm{cm}^{-3}\end{array}$ \\
\hline Oxisol & 4.2 & 13 & 17 & 89 & 9.0 & 3.0 & 0.7 & 3.0 & 474 & 397 & 129 & 21.0 & 1.2 \\
\hline Entisol & 4.3 & 19 & 15 & 56 & 9.0 & 2.0 & 1.4 & 6.0 & 90 & 884 & 26 & 10.0 & 1.6 \\
\hline
\end{tabular}

pH CaCl 2 : pH in calcium chloride; $\mathrm{BS}$ : base saturation; $\mathrm{Al}^{+3}$ : exchangeable aluminum; $\mathrm{Ca}^{+2}$ : exchangeable calcium; $\mathrm{Mg}^{+2}$ : exchangeable magnesium; $\mathrm{P}$ : extractable phosphorus; $\mathrm{K}^{+}$: exchangeable potassium; SOM: soil organic matter; SD: soil density.

In the agronomic assessment of nitrogen fertilizers, two fertilizers were formulated in a fluid form, with ammonium nitrate as raw material $\left(\mathrm{NH}_{4} \mathrm{NO}_{3}\right.$ with $37 \% \mathrm{~N}$ and $1877 \mathrm{~g} \mathrm{~L}^{-1}$ solubility) and distilled water or liquid pig slurry (PS) as solvents, where $21.6 \mathrm{mg} \mathrm{NH}_{4} \mathrm{NO}_{3}$ were dissolved in each liter of solvent, characterizing the treatments N-FM and N-FO, which were compared to $\mathrm{NH}_{4} \mathrm{NO}_{3}$ in the solid form (N-SM) and control without $\mathrm{N}(\mathrm{N}-\mathrm{W})$. The $\mathrm{pH}$ of the nitrogen fluid fertilizers was adjusted to value 6.0.

For pot assembly, a dose of $80 \mathrm{mg} \mathrm{N} \mathrm{pot}^{-1}$ was established, and doses of $140,160,23,1.3,0.9$, and $1.1 \mathrm{mg}$ of potassium, phosphorus, sulfur, copper, zinc, and boron were applied per pot using $\mathrm{KCl}$, triple superphosphate (TSP), $\mathrm{CaSO}_{4}, \mathrm{CuSO}_{4}, \mathrm{ZnSO}_{4}$, and borax as sources, respectively, in a solution form to provide a high availability in the soil, applying the "all-but-one" principle.

To assess phosphate fertilizers, two fertilizers were formulated in a fluid form, with soluble monoammonium phosphate (MAP) as raw material for fertigation $\left(\mathrm{NH}_{4} \mathrm{H}_{2} \mathrm{PO}_{4}\right.$ with $60 \% \mathrm{P}_{2} \mathrm{O}_{5}, 12 \% \mathrm{~N}$, and $374 \mathrm{~g} \mathrm{~L}^{-1}$ solubility) and distilled water or PS as solvents, where $23 \mathrm{~g} \mathrm{NH}_{4} \mathrm{H}_{2} \mathrm{PO}_{4}$ were dissolved in each liter of solvent, characterizing treatments $\mathrm{P}-\mathrm{FM}$ and $\mathrm{P}-\mathrm{FO}$, which were compared to triple superphosphate in the solid form (P-SM) $\left(46 \% \mathrm{P}_{2} \mathrm{O}_{5}\right)$ and control without $\mathrm{P}(\mathrm{P}-\mathrm{W})$. The $\mathrm{pH}$ of the phosphorus fluid fertilizers was adjusted to value 6.0 .

For pot assembly, a dose of $60 \mathrm{mg} \mathrm{P} \mathrm{kg}^{-1}$ was established and a dose of $150 \mathrm{mg} \mathrm{N} \mathrm{kg}^{-1}$ in the form of ammonium nitrate, in addition to the same doses and sources of the other nutrients specified in the $\mathrm{N}$ experiment, except $\mathrm{P}$, were applied per pot. Furthermore, the amount of $\mathrm{N}$ present in the fertilizer MAP (12\% $\mathrm{N})$ that was applied by fluid fertilizers was considered, complementing the application with $\mathrm{NH}_{4} \mathrm{NO}_{3}$ diluted in water to reach a dose of $140 \mathrm{mg} \mathrm{pot}^{-1}$.

PS was collected in a manure tank of full-cycle rearing swine and presented $\mathrm{pH}$ values of 7.2 and total contents of organic matter $(\mathrm{OM}), \mathrm{N}, \mathrm{P}$, and $\mathrm{K}$ of $32,4.8,3.0$, and $2.0 \mathrm{mg} \mathrm{L}^{-1}$, respectively, determined according to RICE et al. (2012). The $\mathrm{pH}$ determination was made by reading with a $\mathrm{pH}$ meter directly in PS samples and nutrient analyzes were carried using "in natura" aliquots of the residue (wet basis).

In both experiments, fertilizers used in fluid or solid forms were incorporated in a $0.04 \mathrm{~m}$ deep furrow in the center of each pot, simulating the localized application in a row and distant $0.04 \mathrm{~m}$ approximately from the seeds, both containing the amounts of nutrients according to the stipulated doses for the test.

Two crop seasons of black oat (Avena strigosa L.) were conducted, one of them in the autumn-winter period (crop 1) and the other in the winter (crop 2), and a crop season with millet (Penissetum glaucum Leeke) in the spring-summer period (crop 3). Eight plants of oat and millet were cultivated per pot, maintained under intermittent irrigation with water aiming at keeping soil moisture always close to $80 \%$ of the soil capacity of each soil.

In each crop season, shoot dry biomass production of plants was determined in a growth period of 55 days after plant germination by cutting them close to the soil surface. The material harvested was dried in a forced-air circulation oven at $60{ }^{\circ} \mathrm{C}$ for 72 hours. Dry mass was determined on a two-decimal-place digital balance. Subsequently, the material was ground in a knife mill until it reached a diameter of less than $1.0 \mathrm{~mm}$ to determine the total contents of $\mathrm{N}$ and $\mathrm{P}$ according to the method described by MALAVOLTA et al. (1997).

The accumulated amount of each nutrient $(\mathrm{mg} / \mathrm{pot})$ was estimated by multiplying its shoot content $\left(\mathrm{g} \mathrm{kg}^{-1}\right)$ by the produced dry mass ( $\left.\mathrm{g} / \mathrm{pot}\right)$. Agronomic efficiency assessment of fluid mineral ( $\mathrm{N}-\mathrm{FM}$ and $\mathrm{P}-\mathrm{FM}$ ) and organomineral (N-FO and P-FO) fertilizers was performed by the agronomic efficiency index (AEI), estimated based on the ratio between the increment promoted by the fluid mineral (N-FM and P-FM) and organomineral (N-FO and P-FO) fertilizers in the amount of $\mathrm{N}$ or $\mathrm{P}$ accumulated by plants concerning the increment promoted by the standard solid mineral fertilizer (N-SM and P-SM), according to the method described by GOEDERT et al. (1986). 
The data were submitted to analysis of homogeneity of variance and normality. After meeting the parametric assumptions, an analysis of variance was performed using the F-test, considering a completely randomized design in a factorial scheme, with the assessment of treatment effect and comparison of means by the Tukey's test $(p<0.05)$.

\section{RESULTS AND DISCUSSION \\ Nitrogen fertilizers}

The highest $\mathrm{N}$ contents in the plant were observed in the first crop of black oat, both for soils and fertilizers. From the second crop, a depletion effect of values up to the third crop with millet can be observed, presenting no interaction (Table 2). In the first crop with black oat, the highest $\mathrm{N}$ contents were provided by fluid organomineral with pig slurry (N-FO) and solid mineral (N-SM) in Entisol and by N-SM in Oxisol, being these values higher in Oxisol than those found in Entisol, except for N-FO.

Table 2. Shoot $\mathrm{N}$ content of black oat plants in crops 1 and 2 and millet in crop 3 in a Typic Quartzipsamment (Entisol) and Typic Hapludox (Oxisol) in response to the application of different types of fertilizers in fluid and solid forms as an $\mathrm{N}$ source.

\begin{tabular}{|c|c|c|c|c|}
\hline \multirow[t]{2}{*}{ Soil } & \multicolumn{4}{|c|}{ Treatment } \\
\hline & $\mathrm{N}-\mathrm{W}$ & \multicolumn{2}{|c|}{ Crop $1\left(\mathrm{~g} \mathrm{~kg}^{-1}\right)$} & $\mathrm{N}-\mathrm{FO}$ \\
\hline $\begin{array}{l}\text { Entisol } \\
\text { Oxisol }\end{array}$ & $\begin{array}{l}12.2 \mathrm{Bc} \\
16.7 \mathrm{Ac}\end{array}$ & $\begin{array}{l}16.9 \mathrm{Ba} \\
26.6 \mathrm{Aa}\end{array}$ & $\begin{array}{l}\text { 14.8 Bbc } \\
20.6 \mathrm{Ab}\end{array}$ & $\begin{array}{l}18.5 \mathrm{a} \\
19.3 \mathrm{~b}\end{array}$ \\
\hline & \multicolumn{4}{|c|}{ Crop $2\left(\mathrm{~g} \mathrm{~kg}^{-1}\right)$} \\
\hline Entisol & 12.2 & 11.5 & 11.3 & 11.5 \\
\hline Oxisol & 12.1 & 13.6 & Crop $3\left(\mathrm{~g} \mathrm{~kg}^{-1}\right)$ & 13.6 \\
\hline Entisol & 5.4 & 4.6 & 4.5 & 4.6 \\
\hline Oxisol & 5.4 & 6.1 & 5.1 & 4.8 \\
\hline
\end{tabular}

Means followed by different letters (lowercase letters on the row and uppercase letters on the column) differ from each other by the Tukey's test $(p \leq 0.05)$. N-W: without nitrogen; N-SM: solid mineral for nitrogen; N-FM: fluid mineral for nitrogen; and N-FO: fluid organomineral for nitrogen.

The highest $\mathrm{N}$ absorption by the first crop is due to two factors. First, regardless the fertilizer form (solid or fluid), the $\mathrm{N}$ mineral forms of ammonium $\left(\mathrm{N}_{-} \mathrm{NH}_{4}{ }^{+}\right)$and nitrate $\left(\mathrm{N}-\mathrm{NO}_{3}{ }^{-}\right)$are little adsorbed by soil colloids and, when adsorbed, form low-energy electrostatic bonds, remaining in the liquid phase of soil (ZHANG et al. 2011). And second, these $\mathrm{N}$ mineral forms are exported from the soil-plant system by plant shoot. Another factor is the high solubility of the ammonium nitrate used to compose the fertilizers, making all $\mathrm{N}$ available in the soil in the first crop.

Nitrogen supply to the soil-plant system promoted a higher shoot dry biomass (DB) in the three crops (Table 3). In the first two crops with black oat, there are difference between fertilizers only in Oxisol, with the lowest values in the treatment without $\mathrm{N}(\mathrm{N}-\mathrm{W})$, which did not differ from $\mathrm{N}-\mathrm{SM}$ in the first crop and from $\mathrm{N}-\mathrm{FM}$ in the second crop, presenting higher values in Oxisol when compared to Entisol. In the third crop, with millet, the residual effect of $\mathrm{N}$ from the fertilizers allowed increasing DB production in Entisol. A difference was observed between soils only for W-N, with DB values higher in Oxisol than were those found in Entisol. The highest DB values for black oat were obtained with N-FO, in the first crop, and N-SM, in the second crop, in Oxisol and for millet with N-FO in QP.

Nitrogen accumulation response in the shoot between fertilizers occurred only in the first crop of black oat. In this sense, the order of magnitude occurred in Oxisol was $\mathrm{N}-\mathrm{SM}>\mathrm{N}-\mathrm{FM} \geq \mathrm{N}-\mathrm{FO}>\mathrm{N}-\mathrm{W}$ whereas in Entisol, an order of magnitude of $\mathrm{N}-\mathrm{FO} \geq \mathrm{N}-\mathrm{SM} \geq \mathrm{N}-\mathrm{FM}>\mathrm{N}-\mathrm{W}$ was observed. When comparing both soils, Oxisol presented higher values of $\mathrm{N}$ accumulation than those found in Entisol.

The application of nitrogen fertilizers in the soil-plant system promoted a higher $\mathrm{N}$ accumulation in the shoot, with the most significant differences observed in the first crop (black oat) with the highest values for $\mathrm{N}-\mathrm{FO}$ and N-SM in Entisol and for N-SM in Oxisol (Figure 1). In the second crop, no differences were observed between fertilizers, demonstrating that no residual effect was found for nitrogen fertilizers. However, significant differences were observed between soils, with higher $\mathrm{N}$ accumulation values in Oxisol when compared to Entisol. In the third crop, no differences were observed between fertilizers or soils. In the sum of three-crop N accumulation, a higher efficiency was found for N-SM in Oxisol and for N-FO and N-SM in Entisol. Also, the highest $\mathrm{N}$ accumulation was observed in Oxisol when compared to Entisol, since Oxisol 
presents higher intrinsic fertility.

Table 3. Shoot dry biomass of black oat plants in the first and second crops and millet plants in the third crop in a Typic Quartzipsamment (Entisol) and Typic Hapludox (Oxisol) in response to the application of different types of fertilizers in fluid and solid forms as an $\mathrm{N}$ source.

\begin{tabular}{|c|c|c|c|c|}
\hline \multirow[t]{2}{*}{ Soil } & \multicolumn{4}{|c|}{ Treatment } \\
\hline & $\mathrm{N}-\mathrm{W}$ & \multicolumn{2}{|c|}{ Crop $1\left(\mathrm{~g} \mathrm{pot}^{-1}\right)$} & $\mathrm{N}-\mathrm{FO}$ \\
\hline $\begin{array}{l}\text { Entisol } \\
\text { Oxisol }\end{array}$ & $\begin{array}{l}40.6 \mathrm{Ba} \\
45.1 \mathrm{Ab}\end{array}$ & $\begin{array}{l}\text { 43.3 } \mathrm{Ba} \\
\text { 47.6 } \mathrm{Ab}\end{array}$ & $\begin{array}{l}44.2 \mathrm{Ba} \\
51.2 \mathrm{Aa} \\
\left.\mathrm{ot}^{-1}\right)\end{array}$ & $\begin{array}{l}42.7 \mathrm{Ba} \\
52.9 \mathrm{Aa}\end{array}$ \\
\hline $\begin{array}{l}\text { Entisol } \\
\text { Oxisol }\end{array}$ & $\begin{array}{r}8.5 \mathrm{Aa} \\
10.3 \mathrm{Ab}\end{array}$ & $\begin{array}{r}9.7 \mathrm{Ba} \\
15.8 \mathrm{Aa}\end{array}$ & $\begin{array}{l}9.2 \mathrm{Ba} \\
\text { 12.6 Aab } \\
\left.\mathrm{ot}^{-1}\right)\end{array}$ & $\begin{array}{l}10.2 \mathrm{Ba} \\
13.8 \mathrm{Aa}\end{array}$ \\
\hline $\begin{array}{l}\text { Entisol } \\
\text { Oxisol }\end{array}$ & $\begin{array}{l}20.0 \mathrm{Bb} \\
26.4 \mathrm{Aa}\end{array}$ & $\begin{array}{l}25.8 \mathrm{Aa} \\
26.7 \mathrm{Aa}\end{array}$ & $\begin{array}{l}24.7 \mathrm{Aa} \\
26.0 \mathrm{Aa}\end{array}$ & $\begin{array}{l}26.4 \mathrm{Aa} \\
26.7 \mathrm{Aa}\end{array}$ \\
\hline
\end{tabular}

Means followed by different letters (lowercase letters on the row and uppercase letters on the column) differ from each other by the Tukey's test $(p \leq 0.05)$. N-W: without nitrogen; N-SM: solid mineral for nitrogen; N-FM: fluid mineral for nitrogen; and N-FO: fluid organomineral for nitrogen.

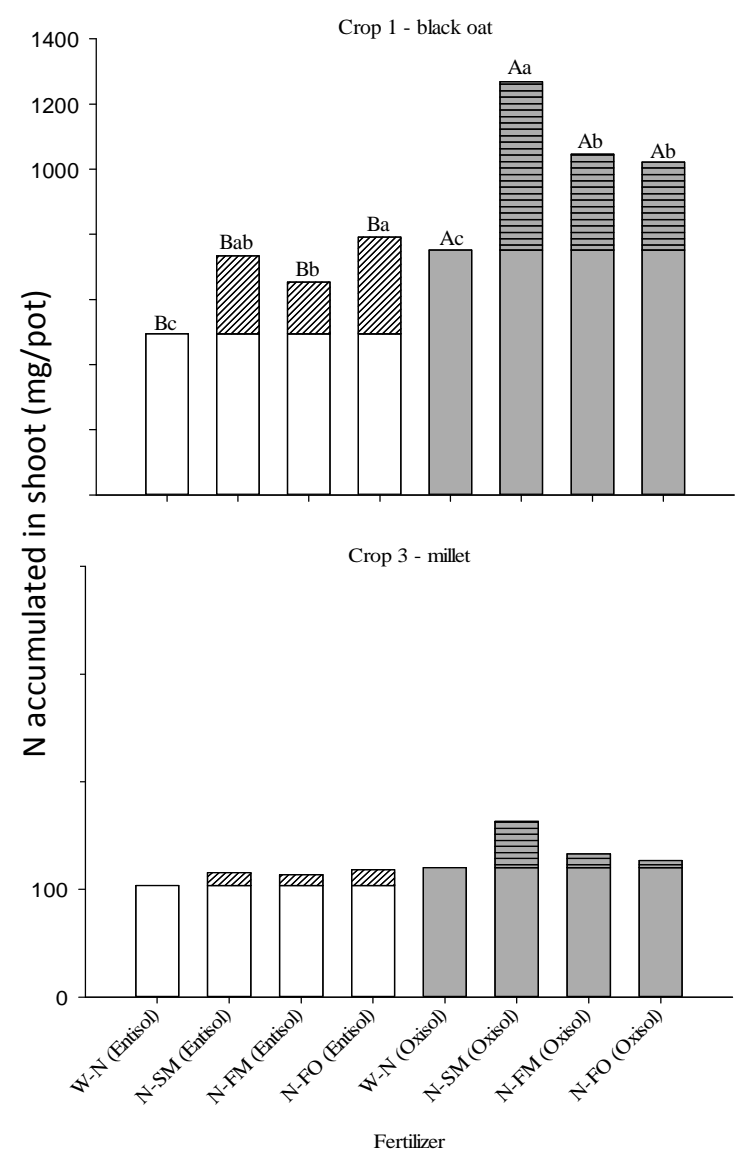

Typic Quartzipsamment (Entisol)

Typic Hapludox (Oxisol)
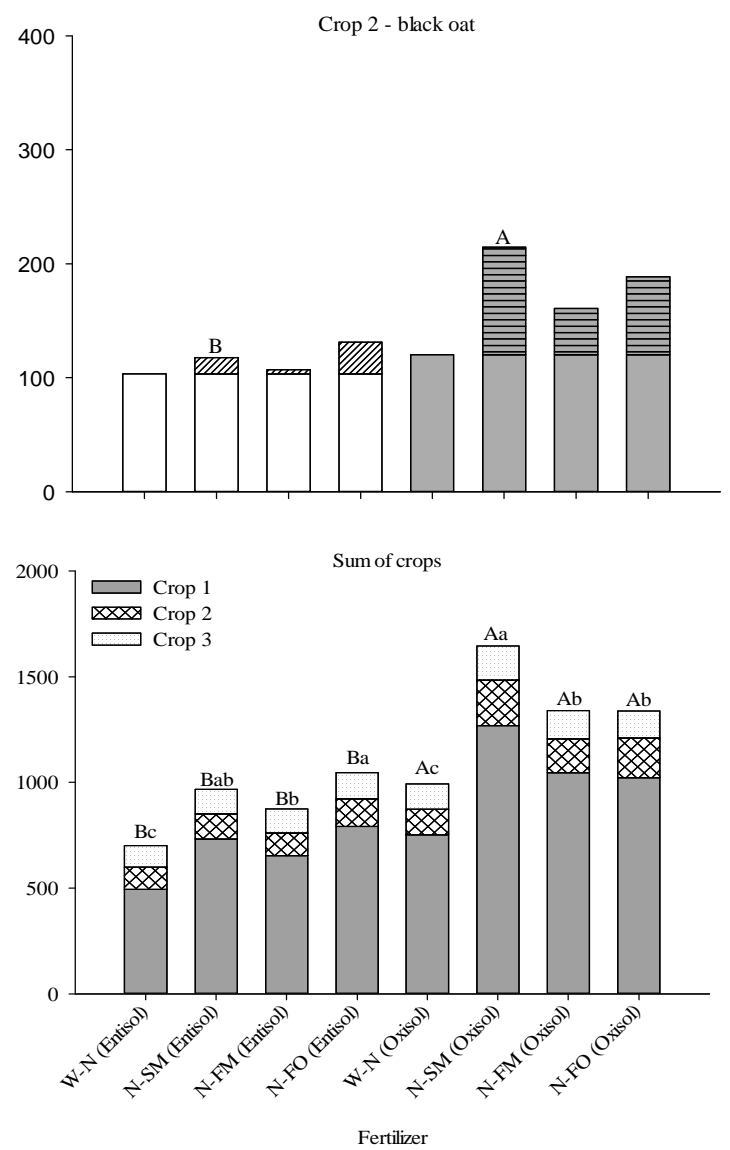

Fertilizer

Fertilizer increment in Entisol in relation to the treatment $\mathrm{N}-\mathrm{W}$

Fertilizer increment in Oxisol in relation to the treatment $\mathrm{N}-\mathrm{W}$

Figure 1. Nitrogen accumulation in shoot of black oat plants in crops 1 and 2 and millet plants in crop 3 in Typic Quartzipsamment (Entisol) and Typic Hapludox (Oxisol) in response to the application of different types of fertilizers in fluid and solid forms as sources of $\mathrm{N}$. Lowercase letters represent the difference between treatments in the same soil and uppercase letters represent the difference between soils in the same treatment by the Tukey's test $(p \leq 0.05)$. 
When assessing the application response of different liquid nitrogen fertilizers in soils with different textures, JARECKI et al. (2008) observed that the presence of soil charges and clay content reduced $\mathrm{N}$ reactions. The higher presence of ion exchange charges in Oxisol allows preserving $\mathrm{N}$ in the system, reducing its transformation process into volatile forms such as ammonia and nitrous oxide (ZHANG et al. 2011, GROHSKOPF et al. 2016) since $\mathrm{N}$ losses in the form of $\mathrm{N}-\mathrm{NO}_{3}{ }^{-}$by leaching are minimal because the pots have a plastic coating, not allowing leaching.

The low residual effect in the second and third crop for $\mathrm{N}$ accumulation in plant shoot is due to soil correction, which raised base saturation to $70 \%$ for both soils, and maintenance of field capacity by $80 \%$.

Based on the agronomic efficiency index (AEI), the fertilizer N-SM, which has ammonium nitrate $\left(\mathrm{NH}_{4} \mathrm{NO}_{3}\right)$ as raw material, presented a higher efficiency when compared to the fluid fertilizer $\mathrm{N}-\mathrm{FM}$ and a lower efficiency when compared to N-FO in both soils for the three crop seasons (Table 4). This N-SM efficiency is due to the longer dissolution time to occur soil reactions, especially in the highest fertility soil (Oxisol), where the highest differences were observed. In the condition of solid fertilizer, soil moisture flux is osmotically induced towards the granules (LOMBI et al. 2006) and part of the initial amount of the added $\mathrm{N}$ remains near the region where the granules were applied even after some time of dissolution.

Fluid fertilizer diffusivity in the soil is higher concerning the solid source, which is subject to soil reactions in a faster form since it does not need the granule physicochemical degradation for displacement (MONTALVO et al. 2015). Among soil and climatic conditions that allowed $\mathrm{N}$ moving in both soils is the maintenance of field capacity in $80 \%$, a factor that contributes to higher efficiency, especially for the nitrogen fertilizer in a solid form.

Table 4. Agronomic efficiency index (AEI) of fluid mineral and organomineral fertilizer with pig slurry as an $\mathrm{N}$ source, estimated for each crop concerning the solid mineral fertilizer $\mathrm{NH}_{4} \mathrm{NO}_{3}$.

\begin{tabular}{|c|c|c|c|c|}
\hline \multirow[t]{2}{*}{ Fertilizer } & \multicolumn{3}{|c|}{ Crop } & \multirow{2}{*}{ Total AEI } \\
\hline & 1 & 2 & 3 & \\
\hline & & $\%$ & & \\
\hline \multicolumn{5}{|c|}{ Typic Quartzipsamment (Entisol) } \\
\hline $\mathrm{N}-\mathrm{FM}$ & 67 & 30 & 82 & 60 \\
\hline $\mathrm{N}-\mathrm{FO}$ & 124 & 167 & 118 & 136 \\
\hline \multicolumn{5}{|c|}{ Typic Hapludox (Oxisol) } \\
\hline $\mathrm{N}-\mathrm{FM}$ & 57 & 43 & 30 & 43 \\
\hline $\mathrm{N}-\mathrm{FO}$ & 52 & 73 & 16 & 47 \\
\hline \multicolumn{5}{|c|}{ Average of both soils } \\
\hline $\mathrm{N}-\mathrm{FM}$ & 62 & 36 & 56 & 51 \\
\hline $\mathrm{N}-\mathrm{FO}$ & 88 & 120 & 67 & 92 \\
\hline
\end{tabular}

Studied the balance of solid and fluid nitrogen fertilization in an Oxisol, LARA-CABEZAS et al. (2000) observed a higher $\mathrm{N}$ preservation when the fluid fertilizer was applied on the soil surface when compared to solid fertilizer in topdressing applied to corn. Also, no difference was observed between both forms when incorporated into the soil.

Only the fertilizer N-FO applied to Entisol presented higher AEI, with values of 24,67 , and $18 \%$, respectively, for crops 1,2, and 3, when compared to the standard solid source of nitrate (N-SM) (Table 4). In this soil, the total AEl, which considers the sum of the three crops, N-FO was $36 \%$ higher than N-SM. This can be related to the presence of organic matter $(\mathrm{OM})$ in pig slurry, which has charges that can maintain $\mathrm{N}-\mathrm{NH}_{4}{ }^{+}$and $\mathrm{N}-\mathrm{NO}_{3}{ }^{-}$adsorbed, preserving it in the system, what is especially important in Entisol since it presents a low ion exchange capacity due to the predominance of quartz in the mineral fraction. On average, $60 \%$ of the total $\mathrm{N}$ in the liquid swine manure is already in the mineral form of $\mathrm{N}-\mathrm{NH}_{4}{ }^{+}$.

\section{Phosphate fertilizers}

The highest $\mathrm{P}$ contents in the plant tissue were observed in Entisol when compared to Oxisol (Table 5). This result is related to the mineral phase of Oxisol, where crystalline forms of iron oxides in the form of goethite and hematite are prevalent and present a high capacity of $\mathrm{P}$ adsorption (SHEN et al. 2011, BOLAN et al. 2013). On the contrary, Entisol shows a predominance of quartz in the sand fraction and small proportions of kaolinite in the clay fraction, making $P$ more available to plants.

Phosphorus addition to the soil-plant system from phosphate fertilizers, regardless of the source or form (fluid or solid), provided higher absorption concerning the absence of fertilization ( $P-W$ ) in both soils 
(Entisol and Oxisol) in the first crop with black oat (Table 5). In the subsequent crops, used to deplete this nutrient in the system, the residual effect of $P$ in Entisol is evidenced, with emphasis for fluid fertilizers (P-FM and $\mathrm{P}-\mathrm{FO}$ ) in the second crop and with an even longer-lasting effect for P-FO in the third crop.

Table 5. Shoot P content of black oat plants in crops 1 and 2 and millet in crop 3 in a Typic Quartzipsamment (Entisol) and Typic Hapludox (Oxisol) in response to the application of different types of fertilizers in fluid and solid forms as a P source.

\begin{tabular}{|c|c|c|c|c|}
\hline \multirow[t]{2}{*}{ Soil } & \multicolumn{4}{|c|}{ Treatment } \\
\hline & \multicolumn{4}{|c|}{ Crop $1\left(\mathrm{~g} \mathrm{~kg}^{-1}\right)$} \\
\hline $\begin{array}{l}\text { Entisol } \\
\text { Oxisol }\end{array}$ & $\begin{array}{l}1.6 \mathrm{~b} \\
1.2 \mathrm{~b}\end{array}$ & $\begin{array}{l}\text { 3.5 } \mathrm{Aa} \\
2.6 \mathrm{Ba}\end{array}$ & $\begin{array}{l}4.5 \mathrm{Aa} \\
2.5 \mathrm{Ba} \\
-1)\end{array}$ & $\begin{array}{l}\text { 4.0 Aa } \\
2.3 \mathrm{Ba}\end{array}$ \\
\hline $\begin{array}{l}\text { Entisol } \\
\text { Oxisol }\end{array}$ & $\begin{array}{l}0.9 \mathrm{c} \\
1.0\end{array}$ & $\begin{array}{l}2.6 \mathrm{Ab} \\
1.5 \mathrm{~B}\end{array}$ & $\begin{array}{l}3.5 \mathrm{Aa} \\
1.5 \mathrm{~B} \\
-1 \text { ) }\end{array}$ & $\begin{array}{l}3.2 \mathrm{Aa} \\
1.5 \mathrm{~B}\end{array}$ \\
\hline $\begin{array}{l}\text { Entisol } \\
\text { Oxisol }\end{array}$ & $\begin{array}{l}0.7 \mathrm{c} \\
0.7 \mathrm{~b}\end{array}$ & $\begin{array}{l}2.5 \mathrm{Ab} \\
1.4 \mathrm{Ba}\end{array}$ & $\begin{array}{l}2.7 \mathrm{Ab} \\
1.4 \mathrm{Ba}\end{array}$ & $\begin{array}{l}3.4 \mathrm{Aa} \\
1.4 \mathrm{Ba}\end{array}$ \\
\hline
\end{tabular}

Means followed by different letters (lowercase letters on the row and uppercase letters on the column) differ from each other by the Tukey's test $(\mathrm{p} \leq 0.05)$. P-W: without phosphorus; P-SM: solid mineral for phosphorus; P-FM: fluid mineral for phosphorus; and P-FO: fluid organomineral for phosphorus.

A higher shoot dry biomass production was observed in plants cultivated in Oxisol when compared to Entisol during the three crops (Table 6). This result is due to soil chemical and physical characteristics, especially the higher soil organic matter (SOM) content and cation exchange capacity present in Oxisol (Table 1).

Fertilization with phosphate fertilizers in fluid or solid forms promoted a higher dry biomass production when compared to their non-addition in the soil-plant system (P-W). In this sense, a difference was observed between fertilizers only for P-FO in the first crop, which presented higher values of dry biomass production when compared to the other fertilizers (Table 6). Organic matter present in liquid pig slurry used to prepare the fluid organomineral (P-FO) may have contributed to reducing $\mathrm{P}$ adsorption only in the region adjacent to fertilizer application.

Table 6. Shoot dry biomass of black oat plants in the first and second crop and millet in the third crop in a Typic Quartzipsamment (Entisol) and Typic Hapludox (Oxisol) in response to the application of different types of fertilizers in fluid and solid forms as a P source.

\begin{tabular}{|c|c|c|c|c|}
\hline \multirow[t]{2}{*}{ Soil } & \multicolumn{4}{|c|}{ Treatment } \\
\hline & P-W & \multicolumn{2}{|c|}{ Crop $1\left(\mathrm{~g} \mathrm{pot}^{-1}\right)$} & P-FO \\
\hline $\begin{array}{l}\text { Entisol } \\
\text { Oxisol }\end{array}$ & $\begin{array}{l}3.2 \mathrm{Ab} \\
1.4 \mathrm{Bc}\end{array}$ & $\begin{array}{l}28.9 \mathrm{Ba} \\
42.8 \mathrm{Ab}\end{array}$ & $\begin{array}{l}26.9 \mathrm{Ba} \\
43.0 \mathrm{Ab} \\
\left.\mathrm{ot}^{-1}\right)\end{array}$ & $\begin{array}{l}31.0 \mathrm{Ba} \\
51.2 \mathrm{Aa}\end{array}$ \\
\hline $\begin{array}{l}\text { Entisol } \\
\text { Oxisol }\end{array}$ & $\begin{array}{l}4.8 \mathrm{~b} \\
2.2 \mathrm{~b}\end{array}$ & $\begin{array}{r}9.2 \mathrm{Ba} \\
18.9 \mathrm{Aa}\end{array}$ & $\begin{array}{l}9.2 \mathrm{Ba} \\
16.9 \mathrm{Aa} \\
\left.\text { ot }^{-1}\right)\end{array}$ & $\begin{array}{l}11.8 \mathrm{Ba} \\
19.8 \mathrm{Aa}\end{array}$ \\
\hline $\begin{array}{l}\text { Entisol } \\
\text { Oxisol }\end{array}$ & $\begin{array}{l}19.5 \mathrm{~b} \\
17.5 \mathrm{~b}\end{array}$ & $\begin{array}{l}38.2 \mathrm{a} \\
42.2 \mathrm{a} \\
\end{array}$ & $\begin{array}{l}33.9 \mathrm{Ba} \\
37.2 \mathrm{Aa}\end{array}$ & $\begin{array}{l}32.6 \mathrm{Ba} \\
37.5 \mathrm{Aa}\end{array}$ \\
\hline
\end{tabular}

Means followed by different letters (lowercase letters on the row and uppercase letters on the column) differ from each other by the Tukey's test $(p \leq 0.05)$. P-W: without phosphorus; P-SM: solid mineral for phosphorus; P-FM: fluid mineral for phosphorus; and P-FO: fluid organomineral for phosphorus.

Fluid mineral fertilizers, when applied in non-concentrated formulations such as 4-10-10 and 3-18-18, allow an increase in $\mathrm{P}$ content available in the soil and a higher absorption by corn plants if the soil is not sandy (REHM \& LAMB 2009). When used during soybean sowing next to the seed, these fertilizers allowed a higher plant growth, absorption, and P concentration in the shoot (REHM \& LAMB 2010). In both studies, the fluid mineral fertilizer was prepared with phosphoric acid as the $P$ source.

In Oxisol, no difference was observed between fertilizers, which presented values of $P$ accumulation 
higher than those found for P-W. On the other hand, in Entisol, an order of magnitude in which $\mathrm{P}-\mathrm{FO}>\mathrm{P}$ FM $>$ P-SM $>$ P-W was observed. Also, when comparing both soils, Oxisol presented higher values of $P$ concerning Entisol in treatments that received fertilizers.

No difference in $\mathrm{P}$ accumulation was observed between Entisol and Oxisol in the first two crops with black oat (Figure 2). However, in the third crop, Entisol presented a higher $\mathrm{P}$ accumulation when compared to Oxisol when considering the fertilizers P-SM, P-FM, and P-FO. Both solid (P-SM) and fluid (P-FM and P-FO) fertilizers increased $\mathrm{P}$ accumulation in plant shoot during the three crops when compared to P-W.

The difference between fertilizers occurred with the application of P-FM and P-FO, which presented higher values than those found for P-SM in Entisol in the first and second crops (Figure 2). However, in the third crop, $\mathrm{P}$-FO presented a higher value of $\mathrm{P}$ accumulation when compared to the other fertilizers in Entisol. For the sum of the three crops, an order of magnitude of P-FO>P-FM>P-SM was observed in Entisol, whereas no difference was observed between fertilizers in Oxisol.

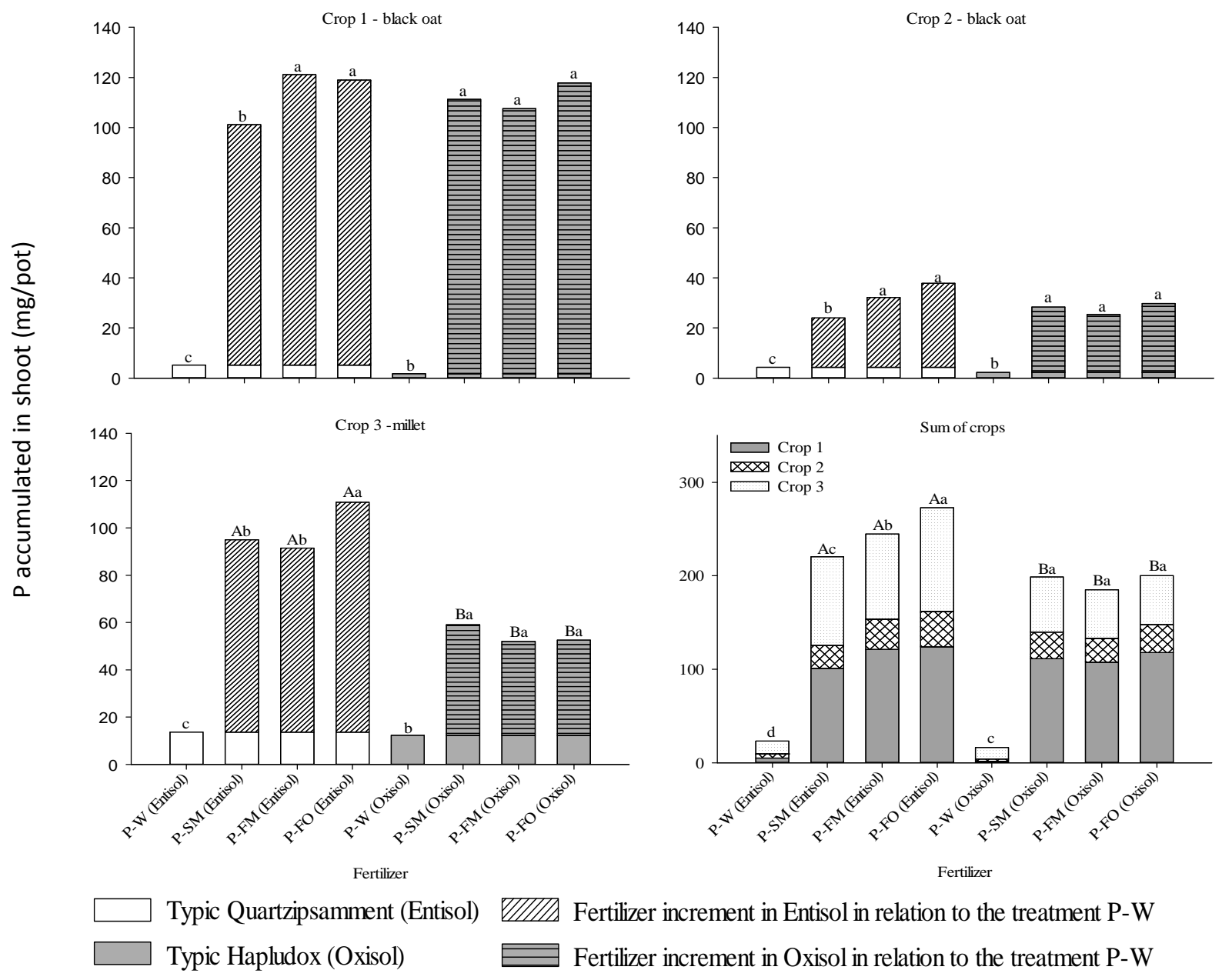

Figure 2. Phosphorus accumulation in shoot of black oat plants in crops 1 and 2 and of millet plants in crop 3 in a Typic Quartzipsamment (Entisol) and Typic Hapludox (Oxisol) in response to the application of different types of fertilizers in fluid and solid forms as sources of $P$. Lowercase letters represent the difference between treatments in the same soil and uppercase letters represent the difference between soils in the same treatment by the Tukey's test $(p \leq 0.05)$.

The agronomic efficiency index (AEI), estimated based on $\mathrm{P}$ accumulated in plant shoot, demonstrated a better efficiency of fluid fertilizers (P-FM and P-FO) when compared to the solid mineral fertilizer (P-SM) in Entisol. In this sense, P-FO presented efficiencies 23, 61, and 19\% higher than were those of P-SM in the three crops, respectively. Similarly, P-FM showed agronomic efficiency 19 and $40 \%$ higher than that observed for P-SM in the first two crops, respectively (Table 7).

In Oxisol, the fertilizer P-FM was less efficient than the solid source P-SM in the three crops (Table 7). The fertilizer P-FO was 6 and 5\% more efficient compared to P-SM in the first and second crops, respectively. In the total AEI, P-FM was less efficient, and P-FO was similar to P-SM. However, in Entisol, P-FM was less efficient concerning P-SM, except for P-FO, with a small superiority in the first two crops. 
The higher AEI in Entisol, when compared to Oxisol, evidences the strong influence of the mineral phase for $P$ availability in the soil-plant system.

Table 7. Agronomic efficiency index (AEI) of fluid mineral and organomineral fertilizer with pig slurry as a $\mathrm{P}$ source, estimated for each crop concerning the solid mineral fertilizer single superphosphate.

\begin{tabular}{|c|c|c|c|c|}
\hline \multirow[t]{2}{*}{ Fertilizer } & \multicolumn{3}{|c|}{ Crop } & \multirow[t]{2}{*}{ Total AEI } \\
\hline & 1 & \multicolumn{2}{|c|}{2} & \\
\hline \multicolumn{5}{|c|}{ Typic Quartzipsamment (Entisol) } \\
\hline P-FM & 119 & 140 & 96 & 118 \\
\hline P-FO & 123 & 161 & 119 & 135 \\
\hline \multicolumn{5}{|c|}{ Typic Hapludox (Oxisol) } \\
\hline P-FM & 96 & 88 & 85 & 90 \\
\hline $\mathrm{P}-\mathrm{FO}$ & 107 & 105 & 87 & 100 \\
\hline \multicolumn{5}{|c|}{ Average of both soils } \\
\hline P-FM & 108 & 114 & 90 & 104 \\
\hline P-FO & 114 & 135 & 102 & 118 \\
\hline
\end{tabular}

MONTALVO et al. (2014) found that fluid mineral phosphate fertilizers did not reduce $P$ fixation in soils rich in oxides, such as the Oxisol of this study. In other words, the use of fluid fertilizers does not reduce $\mathrm{P}$ adsorption reactions with the mineral phase of soil but may increase them because of the greater $P$ diffusion of the fluid fertilizer, presenting no agronomic benefit on granular sources in these soil types (MONTALVO et al. 2015).

In the total $\mathrm{AEI}$, estimated considering the sum of $\mathrm{P}$ accumulation by the three crops, the fertilizers P-FO and P-FM presented efficiencies 36 and 18\% higher than that found for P-SM. In the fluid organomineral fertilizer, the presence of organic matter $(\mathrm{OM})$ in its composition can contribute to reducing $P$ fixation in oxides since $\mathrm{OM}$ competes with $\mathrm{P}$ in these adsorption sites, reducing its fixation, in addition to biological benefits in soil due to organic compound contribution (FERNANDES et al. 2015). The competition between organic anions and phosphate in the adsorption on these sites it is already recognized (SHUAI \& ZINATI 2009).

Working with two materials of an Oxisol with different $\mathrm{P}$ retention capacities, SCIVITTARO et al. (1997) found a similar agronomic efficiency in fluid mineral fertilizers composed of phosphoric acid and monoammonium phosphate when compared to the solid standard source of triple superphosphate in a granule form.

\section{CONCLUSION}

Fluid fertilizers with pig slurry were less efficient in the $\mathrm{N}$ use by crops when compared to the fertilizer in a solid granule form in a Typic Hapludox (Oxisol) but more efficient in a Typic Quartzipsamment (Entisol).

For phosphorus, fluid fertilizers with pig slurry were more efficient when compared to the solid mineral source in a Typic Quartzipsamment and presented the same efficiency in a Typic Hapludox.

Fluid fertilizers prepared with pig slurry demonstrated to be a promising source of $\mathrm{N}$ and $\mathrm{P}$ for crop fertilization, especially in sandy soils as the Entisols. However, more studies are needed with this fertilizer type and its effect on plants and into acid soils of variable charges.

\section{REFERENCES}

BERTRAND I. et al. 2006. Changes in $P$ availability induced by the application of liquid and powder sources of $P, N$, and Zn fertilizers in alkaline soils. Nutrient Cycling in Agroecosystems 74: 27-40.

BOLAN N et al. 2013. Phosphorus-arsenic interactions in variable-charge soils in relation to arsenic mobility and bioavailability. Science of the Total Environment 463-464: 1154-1162.

CAMARGO LA et al. 2014. Clay mineralogy and magnetic susceptibility of Oxisols in geomorphic surfaces. Scientia Agricola 71: 244-256.

CARVALHO WA et al. 1983. Levantamento de solos da fazenda Lageado. Botucatu: UNESP. 95p. (Scientific bulletim 1). DORNELES EP et al. 2015. Tillage, fertilization systems and chemical attributes of a Paleudult. Scientia Agricola 72 : 175-186.

FERNANDES DM et al. 2015. Fósforo na solução do solo em resposta a aplicação de fertilizantes fluidos mineral e organomineral. Irriga 1: 14-27. 
FINK JR et al. 2016. Adsorption and desorption of phosphorus in subtropical soils as affected by management system and mineralogy. Soil and Tillage Research 155: 62-68.

GOEDERT WJ et al. 1986. Princípios metodológicos para avaliação agronômica de fontes de fósforo. Planaltina: Brazilian Agricultural Research Corporation. (Documents 22).

GROHSKOPF MA et al. 2015. Organic Nitrogen in a Typic Hapludox Fertilized with Pig Slurry. Revista Brasileira de Ciência do Solo 39: 127-139.

GROHSKOPF MA et al. 2016. Soil Solution Nutrient Availability, Nutritional Status and Yield of Corn Grown in a Typic Hapludox under Twelve Years of Pig Slurry Fertilizations. Revista Brasileira de Ciência do Solo 40: e0150341.

JARECKI MK et al. 2008. Greenhouse Gas Emissions from Two Soils Receiving Nitrogen Fertilizer and Swine Manure Slurry. Journal Environmental Quality. 37: 1432-1438.

LARA-CABEZAS WAR et al. 2000. Balanço da adubação nitrogenada sólida e fluida de cobertura na cultura de milho, em sistema plantio direto no triângulo mineiro (MG). Revista Brasileira de Ciência do Solo 24: 363-376.

LOMBI E et al. 2006. Speciation and distribution of phosphorus in a fertilized soil: A synchrotron-based investigation. Soil Science Society of America Journal 70: 2038-2048.

MAFRA MSH et al. 2014. Acúmulo de carbono em Latossolo adubado com dejeto líquido de suínos e cultivado em plantio direto. Pesquisa Agropecuária Brasileira 49: 630-638.

MALAVOLTA E et al. 1997. Avaliação do estado nutricional das plantas: princípios e aplicações. 2.ed. Piracicaba: Potafos. 319p.

MALTAS AC et al. 2013. Effect of organic fertilizers and reduced-tillage on soil properties, crop nitrogen response and crop yield: results of a 12-year experiment in Changins, Switzerland. Soil and Tillage Research 126: 11-18.

MONTALVO D et al. 2014. Fluid fertilizers improve phosphorus diffusion but not lability in Andisols and Oxisols. Soil Science Society of America Journal 78: 214-224.

MONTALVO D et al. 2015. Agronomic Effectiveness of Granular and Fluid Phosphorus Fertilizers in Andisols and Oxisols. Soil Soil Science Society of America Journal 79: 577-584.

MÜLLER CRJ et al. 2011. Effects of repeated fertilizer and slurry applications over 38 years on $\mathrm{N}$ dynamics in a temperate grassland soil. Soil Biology and Biochemistry 43: 1362-1371.

REHM GW \& LAMB J. 2009. Corn response to fluid fertilizers placed near the seed at planting. Soil Science Society of America Journal 73: 1427-1434.

REHM GW \& LAMB J. 2010. Soybean response to fluid fertilizers placed near the seed at planting. Soil Science Society of America Journal 74: 2223-2229.

RICE EW et al. 2012. Standard methods for the examination of water and wastewater. 22.ed. Washington: American Public Health Association. 1360p.

SCIVITTARO WB et al. 1997. Eficiência de fertilizantes fosfatados fluidos e sólidos. Revista Brasileira de Ciência do Solo 21: 505-511.

SHUAI X \& ZINATI G. 2009. Proton charge and adsorption of humic acid and phosphate on goethite. Soil Science Society of America Journal 73: 2013-2020.

VAN RAIJ B et al. 2001. Análise química para avaliação da fertilidade de solos tropicais. Campinas: Instituto Agronômico. 285p.

VEIGA $M$ et al. 2012. Chemical attributes of a Hapludox soil after nine years of pig slurry application. Pesquisa Agropecuária Brasileira 47: 1766-1773.

ZHANG JB et al. 2011. Effects of long-term repeated mineral and organic fertilizer applications on soil nitrogen transformations. European Journal of Soil Science 63: 75-85. 